\title{
ANALISIS VARIASI TEMPERATUR PRA MORDAN PEWARNA KAYU SECANG DAN DAUN JATI SERTA PENERAPAN HEDONIC TEST PADA KUALITAS SERAT KENAF INDUSTRI FASHION
}

\section{ANALYSIS OF PRE MORDAN TEMPERATURE VARIATIONS FOR WOODEN DYES AND TEAK LEAVES AND THE APPLICATION OF HEDONIC TESTS ON FIBER QUALITY OF FASHION INDUSTRY}

\author{
Ida Rosanti ${ }^{\star 1}$, Ali Sadikin², Retno Prasetia ${ }^{2}$ \\ ${ }^{1}$ Teknik Industri, Fakultas Teknik, Universitas Nahdlatul Ulama Kalimantan Timur, Jl. KH. \\ Harun Nafsi Kel.Rapak Dalam Kec. Loa Janan Ilir, Samarinda, Indonesia \\ ${ }^{2}$ Teknologi Industri Pertanian, Fakultas Teknik, Universitas Nahdlatul Ulama Kalimantan \\ Timur, JI. KH. Harun Nafsi Kel.Rapak Dalam Kec. Loa Janan Ilir, Samarinda, Indonesia
}

rosaidacitra@gmail.com

\begin{abstract}
This study aims to determine the effect of pre-mordant material on kenaf fiber coloring using secang wood and teak leaves, to determine the Henodic Test method in classifying its quality, as well as to determine the significant effect on the color of kenaf fiber, and to determine the level of consumer preference for kenaf fiber. natural dyes. The research method used was an experiment with a variety of pre-mordant materials (alum, lime, vinegar). From the test, it was found that the color direction of the kenaf fiber was reddish purple to light brown, so the average value of fastness to washing was 4 (good).

From this activity, it was concluded that the addition of secang wood and teak leaves as premordant materials coupled with the effect of $\mathrm{pH}$ on the staining of kenaf fibers with secang wood extract provided variations in the direction of color and the value of color fastness to washing. Kenaf fiber is an environmentally friendly alternative to textile raw materials. This study used the Hedonic Test method with the Kruskal Wallis test. The results of this study were that there was no significant effect on the combination of compost application and pesticide application with natural dyes of secang wood and teak leaves on the color of kenaf fibers and there was no effect on the level of consumer preference for kenaf fiber with natural dyes.
\end{abstract}

Keywords: Kenaf fiber, Hedonic Test, Secang wood, teak leaves, Fashion industry

\section{PENDAHULUAN}

Kalimantan mempunyai kekayaan sumber daya alam dari tumbuhan yang cukup melimpah dan sangat potensial sebagai bahan baku industri yang ramah lingkungan, seperti zat warna alam dari tumbuhan secang dan daun jati yang perlu dikembangkan untuk perkembangan industri tekstil yang berkelanjutan. Potensi lahan pasca penambangan batu bara di wilayah Kalimantan sangat luas dan tidak diproduktifkan kembali. Alternatif pemanfaatan lahan pasca batu bara bisa dipergunakan untuk budidaya tanaman serat kenaf. Tanaman kenaf memiliki daya adaptasi luas sehingga dapat dikembangkan pada berbagai lahan atau tanah seperti lahan banjir, lahan gambut
(Sudjindro, 2009), lahan tadah hujan atau lahan kering. Serat kenaf dari tanaman kenaf (Hibiscus cannabinus $L$ ) umumnya berwarna putih kekuningan dan digunakan sebagai bahan baku industri dan berbagai produk, seperti: tekstil, kertas, pelapis dinding, interior mobil, geotekstil, bahan baku bioful dan lainlain, juga sangat potensial sebagai komoditi ekspor yang dapat meningkatkan perekonomian wilayah Kalimantan.

Proses pewarnaan sangat diperlukan untuk serat kenaf supaya kelihatan lebih menarik bagi konsumen, memiliki nilai estetika seni, dan memiliki nilai daya jual yang tinggi pada serat kenaf yang ramah lingkungan. Pewarna sintetis biasanya digunakan dalam 
pewarna serat karena ketersediaan di pasar lebih banyak, lebih mudah digunakan (Kartina et. Al., 2013), lebih murah, warna lebih stabil dan tidak mudah pudar. Limbah pewarna sintetis menimbulkan pencemaran lingkungan dan merupakan zat yang berbahaya karena beberapa pewarna dapat terdegradasi menjadi senyawa karsionogenik dan beracun (Widjajanti et al., 2011; Kant, 2012). Pewarna alami dalam industri memiliki nilai ekonomis, nilai jual yang tinggi, memiliki nilai estetika seni, warna alami yang dihasilkan lebih khas lebih lembut terlihat natural dan ramah lingkungan.

Seiring meningkatnya pemanfaatan serat kenaf sebagai bahan baku industri otomotif, fiberboard interior mobil, maupun tekstil maka sangat penting bagi desainer atau tim pengembang menggunakan serat kenaf sebagai bahan baku produk fashion untuk memilih bahan baku berdasarkan keindahan (warna), tekstur, dan sentuhan, serta dampak terhadap lingkungan masyarakat sekitarnya. Sehingga penting bagi konsumen sebagai objek yang harus dilihat tolak ukurnya dalam rangka memberikan penilaian atas produk fashion serat kenaf. Menurut Soekarto (1985), tingkat kesukaan konsumen dapat diukur menggunakan uji organoleptik menggunakan alat indera untuk pengembangan produk baru. Menentukan tingkat kesukaan konsumen sangat penting dalam mewujutkan kepuasan konsumen terhadap produk serat kenaf yang dihasilkan dengan diberi pewarna alami kayu secang dan daun jati muda.Hal ini bisa dilakukan dengan penerapan Hedonic Test pada kualitas produk serat kenaf dengan zat warna alami dari kayu secang dan daun jati muda tersebut...

Perkembangan proses pewarnaan tekstil dengan zat warna alam pada umumnya menggunakan proses mordan. Keuntungan proses mordan dapat mengurangi frekuensi pencelupan dari puluhan kali proses pencelupan menjadi 4-5 kali saja. Pada proses mordan posisi unsur hidrogen gugus hidroksil zat warna alam (donor elektron) dapat diganti dengan elemen logam (akseptor). Ikatan yang terjadi adalah ikatan karbonat (semi polar) melalui satu atau lebih pasangan elektron bebas yang diberikan oleh senyawa donor kepada akseptor yang memiliki lintasan kosong (Farida dan Sulaeman, 1998).

Teknik mordanting pada proses pewarnaan tekstil adalah pra mordan dengan menggunakan tawas, kapur dan cuka, karena bahan tersebut merupakan senyawa kimia yang relatif ramah lingkungan. Ada 3 (tiga) jenis bahan yang dipakai sebagai mordan, yaitu tawas, kapur,dan cuka (Vankar, 2002). Penelitian mengenai pengaruh pra mordan terhadap pewarnaan kayu secang (Caesalpinia sappan) merupakan tanaman famili Caesalpinaceae dengan kandungan

Brazilein merupakan zat warna alami yang berwarna merah dari kayu secang. Pada serat kenaf telah dilakukan mordan yang digunakan adalah tawas dan kapur sebagai mordan awal (Thomas, dkk,2013) dan secara simultan (Hamid dan Muhlis, 2005). Adanya pra mordan menambah ketajaman warna dan mengurangi ketahanan luntur warna. Di dalam penelitian ini digunakan variasi bahan pra mordan yaitu campuran minyak kemiri-tawas dan ekstrak jambaltawas untuk pewarnaan serat kenaf menggunakan kayu secang dan daun jati. Daun jati muda berpotensi digunakan sebagai zat warna tekstil yang merupakan zat organik tidak jenuh dan termasuk golongan flavonoid. Adanya kandungan pigmen antosianin pada daun jati menyebabkan warna ungu, ungukemerahan, dan coklat, maka daun jati muda dapat dimanfaatkan sebagai pewarna alam dengan hasil pewarnaan berupa warna-warna yang lebih variatif dan menarik. Penelitian sebelumnya dilakukan untuk memanfaatkan ekstrak daun jati muda sebagai zat pewarna pada kain kapas dengan metode suhu kamar [Ainur Rosyida dan Didik Achadi W, 2014] ${ }^{1}$.

Berdasarkan uraian diatas dan melihat potensi serat kenaf yang sangat besar bagi dunia industri, terutama industri tekstil dan fashion maka penelitian tertarik mencoba meneliti potensi pewarna zat alami menggunakan kayu secang dan daun jati sebagai bahan 
baku pewarna alami untuk serat kenaf yang ramah lingkungan dan melihat seberapa besar tingkat kesukaan konsumen terhadap serat kenaf yang diberi zat warna alami kayu secang dan daun jati dengan beberapa variasi mordan dan temperatur yang berbedabeda.

Tujuan yang ingin dicapai dalam kegiatan penelitian ini, adalah untuk menganalisis pengaruh temperatur dan penggunaan variasi mordan pada pewarna kayu secang dan daun jati pada serat kenaf serta penerapan Hedonic Test pada kualitas serat kenaf pada industri fashion.

\section{METODOLOGI}

\section{Jenis Penelitian}

Penelitian ini merupakan penelitian eksperimen, yaitu untuk menganalisis pengaruh perubahan temperatur dan penggunaan variasi mordan tawas, kapur tohor, dan asam cuka pada pewarna kayu secang dan daun jati muda yang diimplikasikan pada serat kenaf serta penerapan Hedonic Test terhadap konsumen pada kualitas serat kenaf sebagai bahan baku industri fashion.

\section{Waktu dan Tempat Penelitian}

Penelitian ini dilaksanakan dari bulan Januari 2020 sampai dengan bulan Desember 2020 di Laboratorium farmasi Universitas Nahdlatul Ulama Kalimantan Timur.

\section{Target dan Subjeck Penelitian}

Dalam penelitian ini yang menjadi obyek adalah serat kenaf, zat warna alami yaitu ekstrak kayu secang dan ekstrak daun jati muda, bahan mordan larutan tawas, larutan kapur, dan larutan cuka.

\section{Alat dan Bahan}

Alat yang digunakan dalam penelitian ini adalah Pisau stainless steel, Baskom plastik, Pengaduk plastik, Kain saring, Kompor, Panci, Thermometer, Blender, Timbangan analitik, Peralatan Spektrofotometer UV-Vis (1 Set), Pipet filtrat, Gelas ukur, Plastik, Shaker, pH meter, Tempat Penyimpanan, Nampan, gunting, Sendok, Botol plastik, Toples plastik, dan Kertas label.

Bahan baku yang digunakan Serutan kayu secang, Daun jati muda, Air, Aquades, Etanol 60\%, Tawas $\left(\mathrm{Al}_{2}\left(\mathrm{SO}_{4}\right)_{3} \cdot \mathrm{K}_{2} \mathrm{SO}_{4} \cdot 24 \mathrm{H}_{2} \mathrm{O}\right)$, kapur tohor $\left(\mathrm{CaCO}_{3}\right)$, dan asam cuka $\left(\mathrm{CH}_{3} \mathrm{COOH}\right)$.

\section{Proses Mordan dan serat kenaf}

Serat kenaf yang akan diberi zat warna masing-masing akan direndam selama 24 jam dalam larutan mordan, yaitu 50 gram bahan mordan dilarutkan dalam 1 Liter pelarut aquades. Selanjutnya serat kenaf diambil dan dikeringkan dengan cara dianginanginkan. Kemudian agak kering serat kenaf direndam dalam zat warna kayu secang dan daun jati muda.

\section{Rancangan Penelitian}

Rancangan

penelitian menggunakan rancangan acak lengkap (RAL) faktorial dengan 3 faktor, faktor 1 pewarna alami yang terdiri dari 2 taraf yaitu kayu secang dan daun jati, faktor 2 serat kenaf yang terdiri dari 1 taraf yaitu serat kenaf, dan taraf 3 Mordan: Tawas, Kapur tohor, dan asam cuka, masingmasing diulang sebanyak 3 ulangan sehingga total 18 satuan percobaan.

\section{Prosedur Penelitian}

Proses pembuatan pewarna alami dilakukan dengan tiga tahapan yaitu ekstraksi, proses perendaman, dan aplikasi.

1. Persiapan alat

2. Persiapan kayu secang

Kondisi kayu secang harus benarbenar berkualitas bagus untuk diekstraksi, kayu secang diserut kecil-kecil kemudian direbus.

3. Persiapan daun jati

Kondisi daun jati masi muda supaya menghasilkan zat warna yang maksimal, daun jati dibersihkan selanjutnya diblender dan direbus.

4. Proses ekstraksi

Larutan serat kayu secang dan larutan daun jati didinginkan, kemudian diberi etanol dan didiamkan sekitar 30 menit. 
5. Penyaringan filtrat zat warna dengan ampasnya.

6. Pemisahan dan penyaringan filtrat zat warna berdasarkan temperatur yang berbeda.

7. Persiapan bahan larutan Mordan Tawas, Kapur, dan Cuka

8. Merendam serat kenaf dalam larutan mordan Tawas, Kapur, dan Cuka

9. Memisahkan larutan mordan dengan Serat kenaf yang sudah direndam dengan larutan mordan Tawas, Kapur, dan Cuka

10. Serat kenaf mordan direndam dengan larutan zat warna kayu secang dan daun jati muda, berdasarkan masing-masing temperatur, dan jenis mordannya. Serat kenaf mordan di rendam dengan filtrat pewarna kayu secang dan daun jati selama kurang lebih 3 hari

11. Penyaringan dan pemisahan serat kenaf yang sudah dimordan dan sudah direndam dengan filtrat zat warna kayu secang dan daun jati muda.

12. Pengeringan

Serat kenaf organik yang sudah diwarnai dengan pewarna kayu secang dan daun jati dikeringkan tanpa sinar matahari.

\section{Variabel yang diamati}

Variabel yang diamati adalah variasi temperatur pada filtrat zat warna kayu secang dan filtrat daun jati muda, filtrat zat warna kayu secang dan daun jati setelah dan sesudah direndami serat kenaf yang dimordan dengan tawas, kapur, dan cuka. Serta tingkat kesukaan konsumen terhadap serat kenaf yang sudah di mordan dan direndam dengan zat warna alami kayu secang dan daun jati.

\section{Analisis data}

Data diuji dengan menggunakan metode Hedonic test, menggunakan kuesioner dengan panelis (kosumen) tidak terlatih sebanyak 20 orang dengan data yang diperoleh berdasarkan pada respons panelis menggunakan skala hedonis dianalisis dengan uji KruskalWallis. Data yang diuji warna, bau atau aroma, dan tekstur dari serat kenaf yang diberi zat warna kayu secang dan daun jati muda dengan pelarut aquades dan etanol $60 \%$.

Warna adalah persepsi yang muncul di otak manusia saat melihat pantulan cahaya pada suatu objek. Warna dipegaruhi oleh komposisi fisik dan kimia dari suatu objek cahaya yang dipantulkan, dan sensivitas mata seseorang (Lawless \& Heymann, 2010).

Warna adalah presepsi yang muncul di otak manusia saat melihat pantulan cahaya pada suatu objek. Warna dipengaruhi oleh komposisi fisik dan kimia dari suatu objek, cahaya yang dipantulkan, dan sensitivitas mata seseorang (Lawless dan Heymann, 2010). Warna adalah kesan pertama yang ditangkap panelis sebelum mengenali rangsangan lain. Warna sangat penting untuk setiap makanan sehingga warna yang menarik akan mempengaruhi penerimaan konsumen (De man, 1987).

Aroma atau bau adalah salah satu faktor yang menentukan kesukaan seseorang akan makanan. Bau dapat memberikan persepsi rasa tertentu dalam makanan (Kartika, 1988). Bau adalah salah satu standar uji dalam serat kenaf yang diwarnai dengan pewarna alami karena bau pewarna dari pewarna alami memiliki bau khas masing-masing pewarna alami. Testur dalam makanan sangat penting bagi konsumen, tekstur lebih digunakan sebagai patokan untuk kualitas makanan (Lawless\&Heymann, 2010). Dalam penelitian ini kuisioner dengan skala penilaian sangat suka :7, suka: 6 , agak suka:5, netral/biasa:4, agak tidak suka:3, tidak suka:2, dan sangat tidak suka:1.

\section{HASIL DAN PEMBAHASAN}

\section{Proses Pembuatan ekstrak pewarna alami Kayu Secang dan Daun Jati Muda}

Proses eksplorasi pengambilan pigmen zat warna alam dari kayu secang (Caesalpinia sappan) dan daun jati (Tectona garndis) dengan di ekstrak disebut proses ekstraksi. Proses ekstraksi dilakukan dengan merebus bahan serutan kayu secang maupun 
daun jati muda dengan pelarut aquades dan ethanol $60 \%$ selama kurang lebih 15 menit sampai 60 menit, hal ini terdapat perubahan temperatur dalam prosedur penelitian yaitu 30 menit dikarenakan dalam pengambilan sample filtrat dilakukan pada beberapa variasi temperatur dan waktu dengan tujuan untuk mengetahui tingkat kestabilan, daya serap dan intensitas panjang gelombang zat warna dari kayu secang dan daun jati muda melalui beberapa variasi temperatur diantaranya $40^{\circ} \mathrm{C}$, $55^{\circ} \mathrm{C}, \quad 70^{\circ} \mathrm{C}$ dengan pendekatan temperatur berkisar antara $60^{\circ} \mathrm{C}$. Bagian tumbuhan yang akan diekstrak warnanya dipotong-potong kecil, kemudian 500 gram bahan dilarutkan dalam 4 Liter pelarut aquades dan ethanol $60 \%$ dengan perbandingan $1: 8 \mathrm{~m} / \mathrm{v}$ atau 500 gram:4 Liter, kemudian larutan direndam selama 224 jam. Selanjutnya larutan tersebut direbus dengan api kecil dengan memperhatikan temperatur larutan dan supaya dihindari jangan sampai temperatur larutan serutan kayu secang dan daun jati terlalu tinggi atau panas sampai volume larutan tersisa setengahnya. Kemudian rendaman serat kayu secang direbus pada temperatur $50^{\circ} \mathrm{C}$ sampai $70^{\circ} \mathrm{C}$ selama kurang lebih

60 menit, selanjutnya hasil rebusan serutan kayu secang didinginkan selama kurang lebih 1 jam, kemudian larutan serutan kayu secang diberi setelah itu filtrat disaring dengan kain saringan dan dipisahkan dari ampasnya.

Proses berikutnya menimbang daun jati muda sebanyak 500 gram, kemudian daun jati muda dilarutkan dalam etanol $60 \%$ dan aquades masimgmasing sejumlah 5 Liter. Proses selanjutnya diblender dan didiamkan kurang lebih selama $2 \times 24$ jam, setelah 2 hari rendaman filtrat daun jati muda dan ethanol $60 \%$ direbus kurang lebih 60 menit, waktu perebusan serutan kayu secang dan daun jati muda ada perubahan waktu dari yang direncakan karena sifat etanol $60 \%$ mudah menguap dikawatirkan jika terlalu lama merebusnya maka kandungan etanol dalam larutan akan menguap dan hilang. proses perebusan daun jati muda larutan
Setelah didiamkan selama kurang lebih 1 jam.

Dalam proses ekstraksi larutan kayu secang dan daun jati harus benar-benar diperhatikan perubahan temperaturnya, karena apabila terjadi temperaturnya terlalu tinggi atau panas melewati batas yang ditetapkan untuk menghasilkan zat warna yang maksimum apalagi sampai melebihi batas titik didihnya maka zat warna tersebut akan tergradasi dan menghasilkan zat warna yang tidak berkualitas.

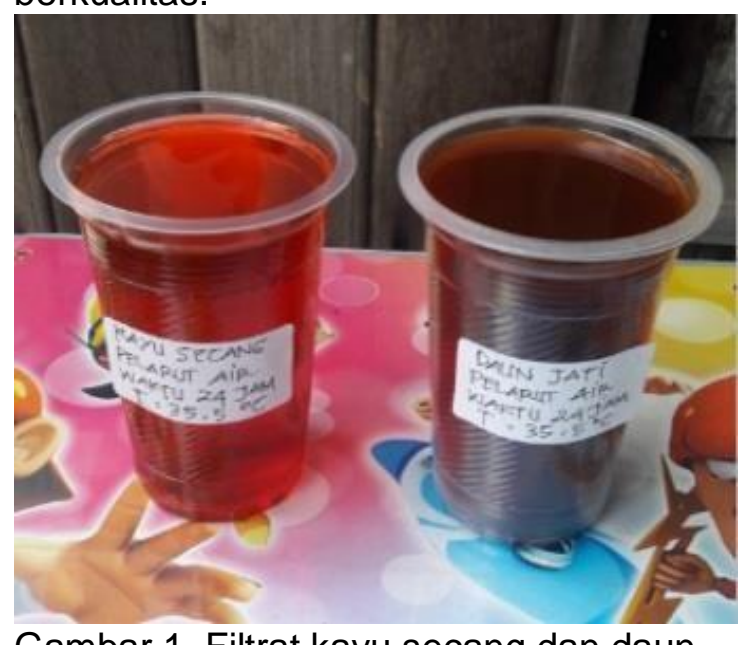

Gambar 1. Filtrat kayu secang dan daun jati

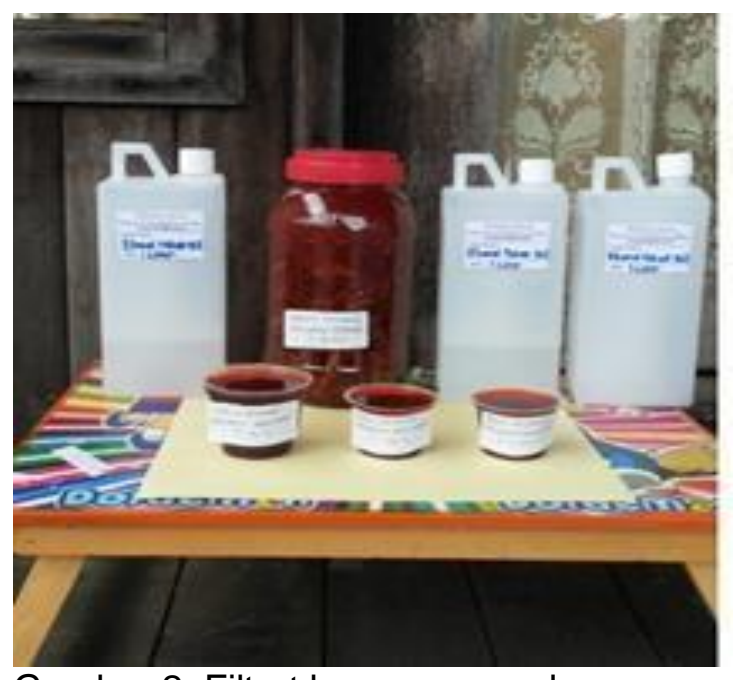

Gambar 2. Filtrat kayu secang dengan pelarut etanol $60 \%$ 


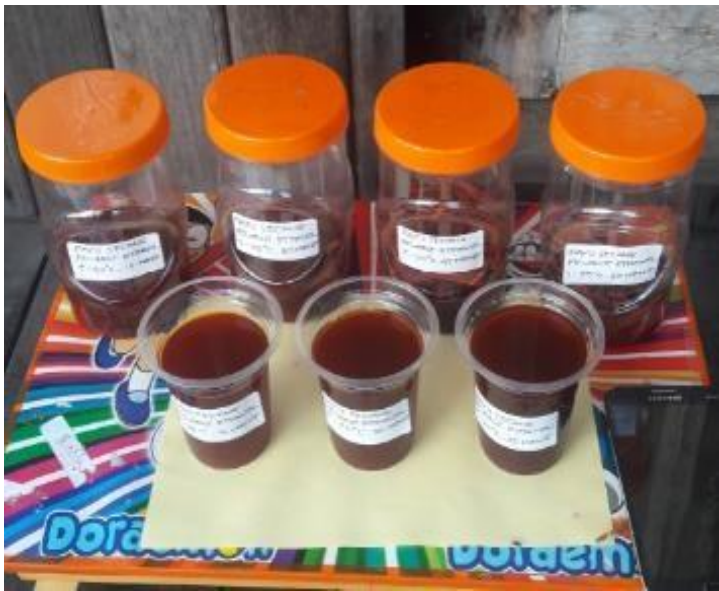

Gambar 3. Filtrat kayu secang dengan pelarut etanol $60 \%$ dengan temperatut $40^{\circ} \mathrm{C}, 55^{\circ} \mathrm{C}$, dan $70^{\circ} \mathrm{C}$

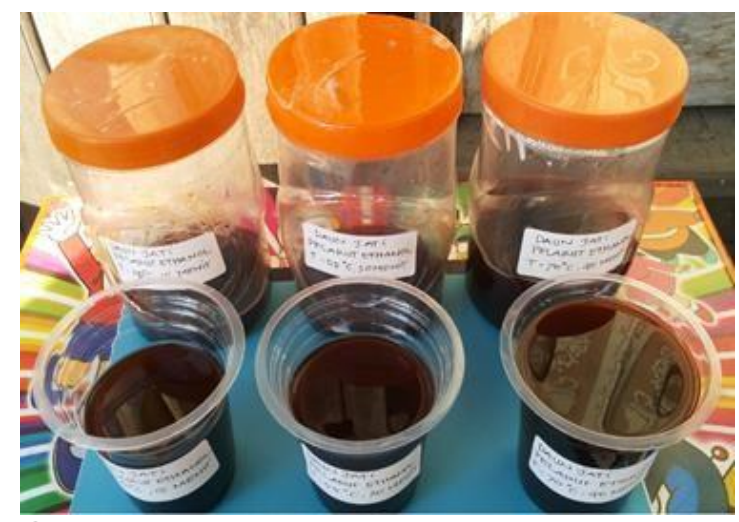

Gambar 4. Filtrat Daun jati dengan pelarut etanol $60 \%$ dengan temperatut $40^{\circ} \mathrm{C}, 55^{\circ} \mathrm{C}$, dan $70^{\circ} \mathrm{C}$

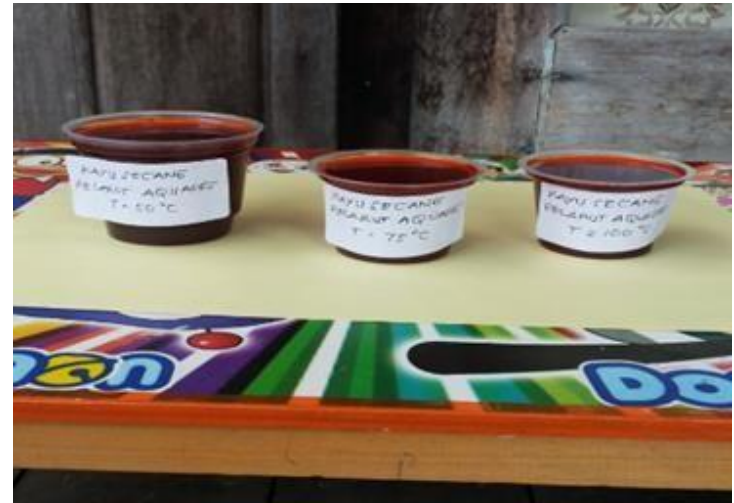

Gambar 5. Filtrat kayu secang dengan pelarut aquades pada temperatur $50 \stackrel{\circ}{\circ}, 75^{\circ} \mathrm{C}$ dan $100 \stackrel{\circ}{\circ} \mathrm{C}$

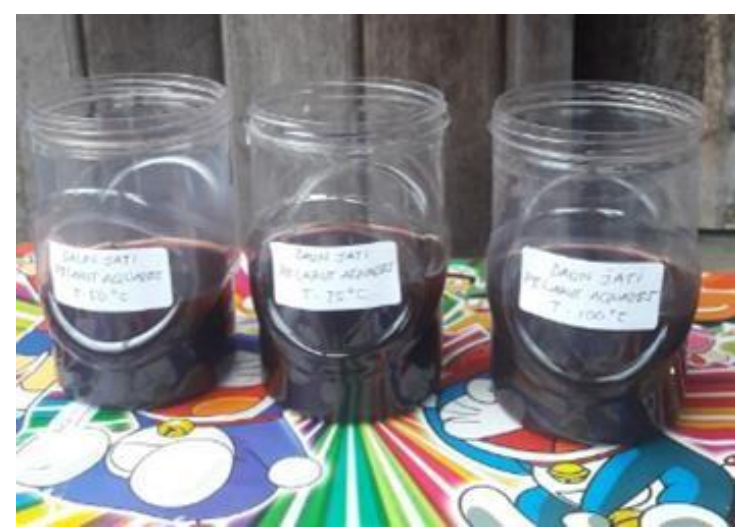

Gambar 6. Filtrat Daun jati dengan pelarut aquades pada temperatur $50^{\circ} \mathrm{C}$, $75^{\circ} \mathrm{C}$ dan $100^{\circ}$

Tabel 1. Zat Warna Kayu Secang Pelarut Etanol 60\%

Mordan -




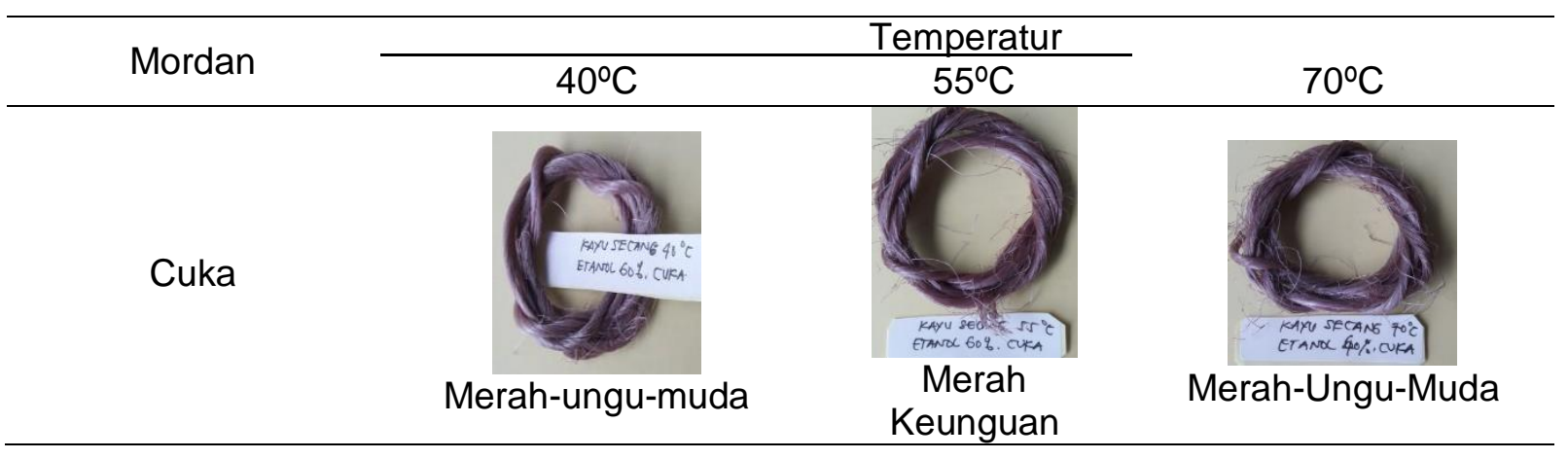

Tabel 2. Zat Warna Daun Jati Pelarut Etanol 60\% Mordan

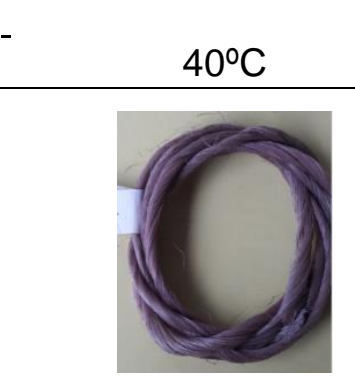

Merah kecoklatan

Kapur

Tawas

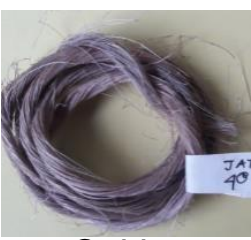

Coklat

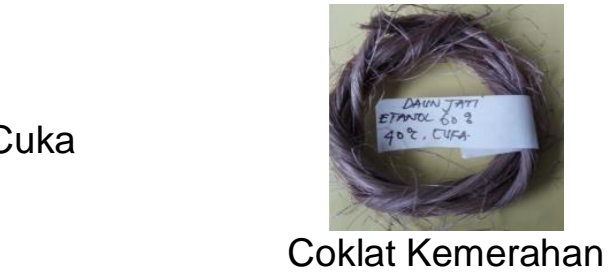

Coklat Kemerahan

Cuka

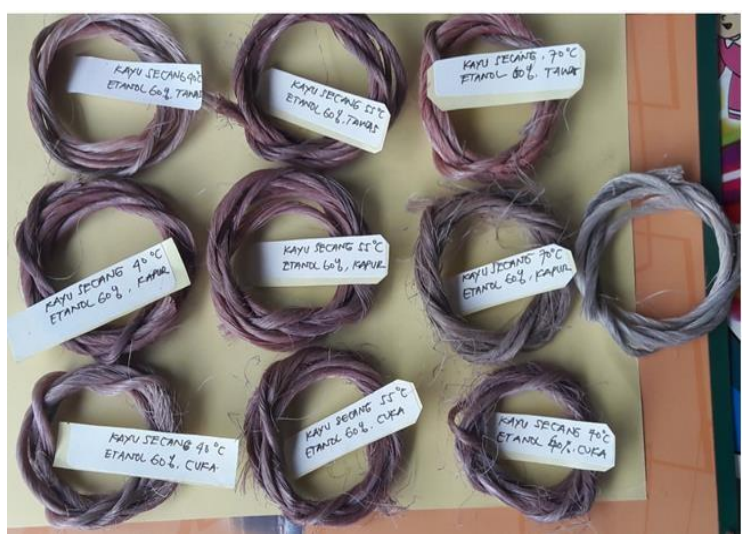

Gambar 7. Serat kenaf yang direndam filtrat kayu secang dengan pelarut etanol $60 \%$ pada temperatur $40^{\circ} \mathrm{C}, 55^{\circ} \mathrm{C}$, dan dan $70^{\circ} \mathrm{C}$ dengan mordan tawas, kapur, dan cuka.
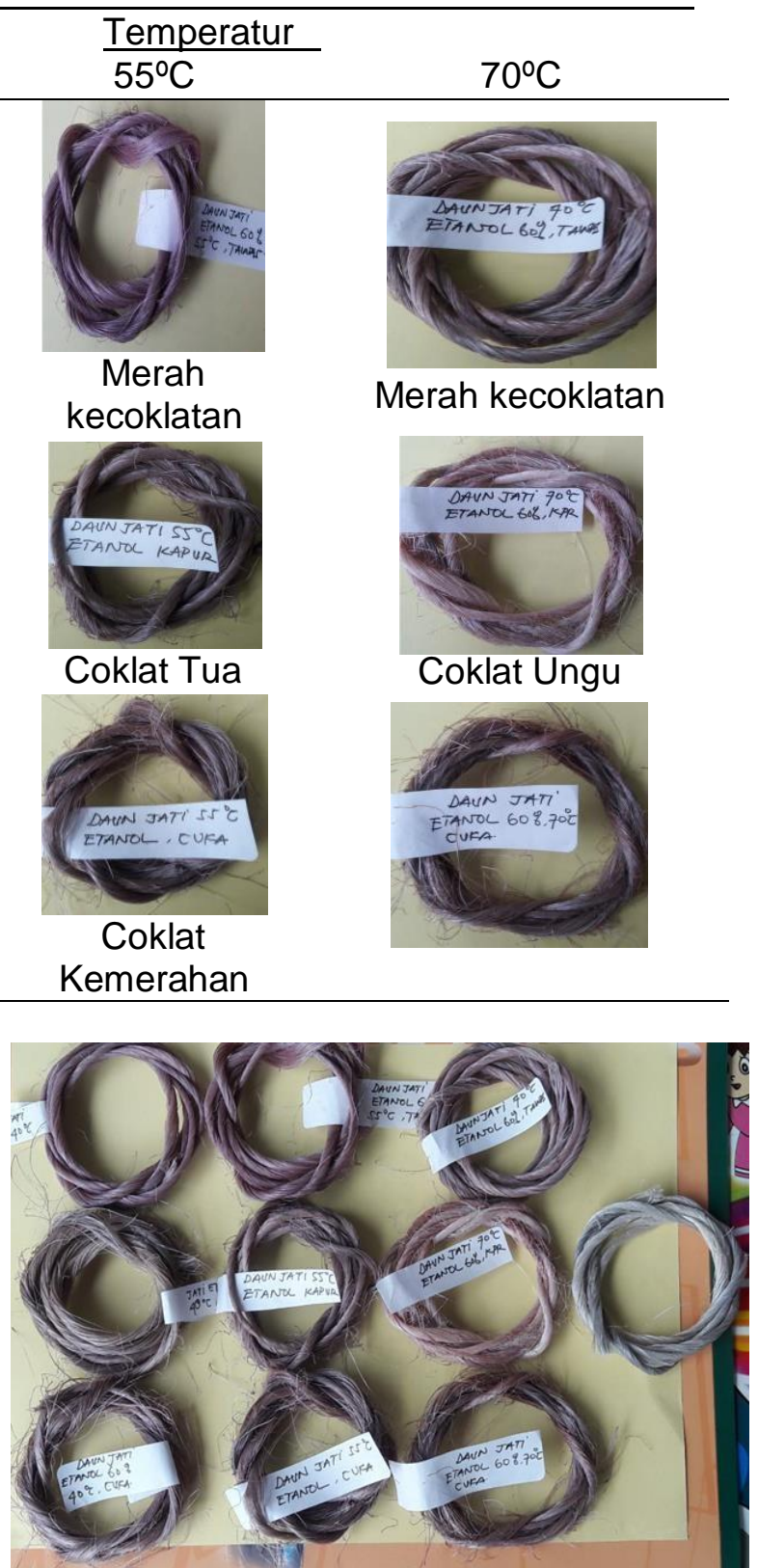

Gambar 8. Serat kenaf yang direndam filtrat daun jati dengan pelarut etanol $60 \%$ pada temperatur $40^{\circ} \mathrm{C}, 55^{\circ} \mathrm{C}$, dan $70^{\circ} \mathrm{C}$ dengan mordan tawas, kapur, dan cuka. 
Pada tabel 1 ditunjukkan warna serat kenaf pada temperatut $40^{\circ} \mathrm{C}, 55^{\circ} \mathrm{C}$ dan $70^{\circ} \mathrm{C}$ pelarut etanol $60 \%$ dengan mordan tawas, kapur tohor dan asam cuka mengalamai perubahan warna. Arah warna serat kenaf merah keunguan tua mengalami perubahan seiring dengan perubahan temperatur dan jenis mordan yang digunakan. Pada tabel menunjukkan perubahan temperatur tidak signifikan terhadap perubahan arah warna serat kenaf, hal ini dikarenakan perubahan temperatur tidak begitu berpengaruh terhadap perubahan warna serat kenaf apabila sebelum pewarnaan serat kenaf menggunakan bahan mordan. Dalam hal ini yang menjadi sangat dominan pada perubahan arah warna adalah penggunaan jenis mordan tawas, kapur tohor, dan asam cuka. Penggunaan mordan dapat menambahkan kelompok kromofor dalam serat yang menyebabkan warna pewarna menjadi lebih tua jika dibandingkan dengan pewarna serat tanpa mordan. Hal ini didukung penelitiannya Zheng et.al., (2011) dan Pawar, et. Al (2017) menyatakan bahwa modifikasi bahan kimia alami dari pewarna alami dapat digunakan untuk mengatasi keterbatasan pewarna alami seperti kekuatan tinctorial yang buruk, kurangnya reproduktivitas karena berbagai kemurnia dan sifat tahan luntur yang lebih rendah untuk aplikasi skala besar tanpa adanya dari mordan.

Zat warna kayu secang pada suhu ekstrak $75^{\circ} \mathrm{C}$ dan $100^{\circ} \mathrm{C}$ dengan menggunakan pelarut aquades pada serat kenaf mampu memberikan warna merah yang kuat tetapi setelah proses fiksasi dan dilanjutkan proses plorodan arah warna serat kenaf berubah dari warna merah kuat menjadi ke merah muda pada semua jenis perlakuan fiksasi. Setelah proses pengeringan.

Pada tabel 2 ditunjukkan bahwa arah warna serat kenaf menggunakan zat warna daun jati muda pelarut etanol $60 \%$ pada perubahan temperatur $40^{\circ} \mathrm{C}, 55^{\circ} \mathrm{C}$ dan $70^{\circ} \mathrm{C}$ dengan mordan tawas, kapur tohor dan asam cuka mengalamai sedikit perubahan. Arah warna serat kenaf sangat dipengarugi oleh jenis mordan tawas, kapur tohor, dan asam cuka yang digunakan. Dalam tabel warna serat kenaf pada temperatur $40^{\circ} \mathrm{C}$ dengan mordan tawas menghasilkan warna merah kecoklatan, dilanjutkan dengan perubahan temperatur pada $55^{\circ} \mathrm{C}$ arah warna serat kenaf masih tetap merah kecoklatan, pada temperatur $70^{\circ} \mathrm{C}$ warna serat kenaf mengalami sedikit perubahan menjadi merah kecoklatan lebih muda sedikit. Arah warna serat kenaf berubah menjadi coklat dengan menggunakan mordan kapur tohor, dan serat kenaf menjadi coklat kemerahan dengan menggunakan larutan mordan asam cuka.

Warna serat kenaf menjadi merah keungungan tua dengan pewarna kayu secang pelarut aquades pada temperatur $100^{\circ} \mathrm{C}$ dengan menggunakan mordan kapur. Arah warna serat kenaf menjadi merah keunguan $\mathrm{m}$

uda dengan menggunakan mordan tawas, dan serat kenaf berubah warna menjadi merah keunguan lebih muda lagi dengan menggunakan mordan asam cuka.

Warna serat kenaf menjadi merah kecoklatan tua pada zat warna daun jati pelarut aquades pada temperatur $75 \stackrel{\circ}{\circ} \mathrm{C}$ dengan menggunakan mordan tawas. Arah warna serat kenaf berubah menjadi merah kecoklatan muda dengan menggunakan tawas kapur, dan serat kenaf berubah warna menjadi merah kecoklatan lebih muda lagi dengan menggunakan mordan cuka

\section{Tingkat Preferensi Organoleptik terhadap warna, tekstur, dan bau.}

Berdasarkan hasil analisis KruskalWallis terhadap tingkat kepuasan konsumen terhadap warna serat kenaf tidak menunjukkan bahwa tidak ada perbedaan yang signifikan dalam preferensi konsumen untuk warna, tekstur dan bau serat kenaf dengan pewarna alami kayu secang dan daun jati muda. Tingkat favorit konsumen menyatakan bahwa rata-rata panelis menyukai warna, tekstur dan bau dari serat kenaf dengan pewarna kayu secang dan daun jati muda. Dari persentase rata-rata $45 \%$ menunjukkan bahwa panelis menyukai pewarna kayu secang dan daun jati muda, karena warna serat kenaf tidak berbeda secara statistik karena dalam uji organoleptik pewarna alami relatif sama sehingga panelis tidak dapat 
membedakan warna serat kenaf dengan pewarna alami dibandingkan pewarna sintetis.

Berdasarkan hasil analisis yang dilakukan dan telah diperoleh dari segi tekstur serat kenaf, tidak ada perbedaan tingkat preferensi konsumen antara kombinasi zat warna kayu secang dan daun jati muda. Berarti setiap jenis pewarna alami memberikan efek yang sama terhadap preferensi setiap orang untuk tekstur serat kenaf dengan pewarna alami.

Hasil analisis menunjukkan dalam hal bau serat kenaf, tidak ada perbedaan tingkat preferensi konsumen antara kombinasi pewarna alami kayu secang dan daun jati muda pada serat kenaf, hal ini berarti setiap jenis pewarna alami memberikan efek yang sama pada serat kenaf.

\section{KESIMPULAN}

Pada perubahan temperatur zat warna kayu secang dan daun jati dengan pelarut etanol $60 \%$ maupun aquades terhadap serat kenaf tidak menunjukkan perubahan yang signifikan pada perubahan temperatur, karena penggunaan larutan mordan pada serat kenaf lebih terlihat dominan dan sangat mempengaruhi dalam menentukan hasil akhir proses perendaman serat kenaf dengan zat warna kayu secang maupun daun jati muda, hal ini juga dipengaruhi oleh kandungan ion yang ada pada senyawa-senyawa mordan tawas, kapur tohor, dan asam cuka yang mampu mengikat secara maksimal zat warna kayu secang dan daun jati muda, sehingga menyebabkan permukaan serat kenaf menyerap ion-ion zat pewarna alam tersebut, dan menyebabkan serat kenaf memiliki kualitas warna yang berbedabeda bergantung pada variasi jenis mordan yang digunakan.

Berdasarkan hasil analisis respon panelis menggunakan metode Hinodic Test dengan uji Kruskal Wallis hasil penelitian menunjukkan bahwa tidak ada perbedaan yang signifikan dalam preferensi konsumen untuk warna, tekstur dan bau serat kenaf dengan pewarna alami kayu secang dan daun jati muda dari persentase tingkat favorit konsumen menyatakan bahwa rata-rata panelis menyukai warna tersebut, tekstur dan bau dari serat kenaf dengan pewarna alami kayu secang dan daun jati.

\section{UCAPAN TERIMA KASIH}

Peneliti mengucapkan terima kasih kepada Kemenristek Dikti atas pendanaan Penelitian Dosen Pemula 2020.

\section{DAFTAR PUSTAKA}

Endah Sulistiawati. 2017. Ekstraksi Zat Warna Alami dari Daun Jati Muda (Tectona grandis) dan Kayu Secang (Caesalpinia sappan L.) dengan Metode Ultrasound Assisted Extraction untuk Applikasi Produk Tekstil.

Aminuddun Baharuddin, Aisyah, Jawiana Saokani dan Inda Ayu Risnah. 2015. Karateristik Zat Warna Daun Jati (Tectona grandis) Fraksi Metanol:n- Heksana Sebagai Photosensitizer pada Dye Sensitized Solar Cell.

Ainur Rosyida dan Didik Achadi W. 2014. Pemanfaatan Daun Jati Muda untuk Pewarnaan Kain Kapas Pada Suhu Kamar.

Dian Aulia. 2018. Pengaruh Pelarut pada Ekstraksi Tanaman Kayu Secang (Caesalpinia sappan L.) dengan Menggunakan Metode Ultrasonifikasi dan Maserasi.

Dian Mutmainah. 2018. Ekstraksi dan Uji Stabilitas Zat Warna Alami dari Daun Jati (Tectona grandis Linn.

$F$ Sebagai Bahan Pengganti Pewarna Sintetik pada Produk Minuman. 217.

Dwi Wiji Lestari, Isnaini, Irfa'ina Rohana Salma, dan Yudi Satria. 2018. Bentonit Sebagai Mordan Dalam Pewarnaan Alami pada Batik Menggunakan Kayu Secang (Caesalpinia Sappan Linn).

Endah Sulistiawati dan Prima Swastika. 2017. Ekstraksi Zat Warna Alami dari Daun Jati Muda (Tectona grandis) dan Kayu Secang (Caesalpinia Sappan Linn) dengan Metode Ultrasound Assisted 
Extraction untuk Aplikasi Produk Tekstil. 2017.

F.Failisnur, S Sofyan, S Silfia. 2019. Ekstraksi Kayu Secang (Caesalpinia sappan Linn) dan aplikasinya pada pewarnaan kain katun dan sutera. 2019.

Farida, Vivin Atika, dan Agus Haerudin. 2015. Pengaruh Variasi Bahan Pra Mordan Pada Pewarna Batik Menggunakan akar mengkudu (Morinda citrifolia).

Hernani, Risfaheri dan Tatang Hidayat. 2017. Ekstraksi dan Aplikasi Pewarna Alami Kayu Secang dan Jambal dengan Beberapa Jenis Pelarut.

Junaidi, 2010. Statistik Uji Kruskal Wallis. Fakultas Ekonomi Universitas Jambi, Jambi.

Ramdana Sari dan Suhartati, 2016. Secang (Caesalpinia sappan. L) : Tumbuhan Herbal Kaya Antioksidan. Info Teknis Eboni. Vol.13 No.1, Juni 2016.

Rusmini dan Nurlaila, 2016. Pengaruh Pupuk Organik Cair Terhadap Pertumbuhan dan Hasil Tanaman Kenaf, Buletin Loupe Vol.13 No.2.

Rusmini, Manulang RR, Aquastini D, Daryono, Ali Sadikin. 2018.The Areca Nut (Areca Catechu L.) As $A$ Natural Dye On Organic Kenaf Fiber.

Rusmini, Riama Rita Manullang dan Daryono. 2018. Bididaya Kenaf Organik. Politeknik Pertanian Negeri Samarinda. 2018.

Saadatul Husna. 2017. Deteksi Tiga Zat Warna dalam Kayu Secang (Caesalpinia sappan) Menggunakan Kombinasi Spektroskopi UV-VIS dan Kemometrika. Hak Cipta Institut Teknologi Bogor.

Saeful Amin dan Anna Yuliana, 2016. Analisis dan Uji Kestabilan Zat Warna Kayu Secang (Caesalpinia sappan L.) Menggunakan Spektrofotometeruv-visible dan Inframerah. Jurnal Kesehatan Bakti Tunas Husada, Volume 15 Nomor 1 Februari 2016.

Titiek Pujilestari dan Irfa'ina Rohana Salma. 2017. Pengaruh Suhu
Ekstraksi Warna Alam Kayu Secang (Caesalpinia sappan Linn) dan Gambir (Uncaria gambir) Terhadap Kualitas Warna Batik. 2017.

Yenni Karlina, Putranti Adirestuti, Dewi Meliati Agustini, Nurul Laily Fadhilah, Nida Fauziyyah, Desi Malita. 2016. Pengujian Potensi Antijamur Ekstrak Air Kayu Secang Terhadap Aspergillus niger dan Candida albicans. dst.

Penelitian sebelumnya dilakukan untuk memanfaatkan ekstrak daun jati muda sebagai zat pewarna pada kain kapas dengan metode suhu kamar [Ainur Rosyida dan Didik Achadi W, 2014] $]^{1}$ 